\title{
Transkripsiyon metinlerinde çok dilli eserler: Sözlülkler, gramer kitapları, rehberler
}

\section{Yakup YILMAZ}

\begin{abstract}
APA: Yılmaz, Y. (2019). Transkripsiyon metinlerinde çok dilli eserler: Sözlükler, gramer kitapları, rehberler. RumeliDE Dil ve Edebiyat Araștırmalar Dergisi, (Ö6), 79-95. DOI: 10.29000/rumelide.648425.
\end{abstract}

\section{$\ddot{O} \mathbf{z}$}

Transkripsiyon metinleri Codex Cumanicus’tan bu yana Türkçenin söz varlığı ve onun sesletimi için öncelikli kaynaklardandır. Gramer kitapları, sözlükler ve rehberlerden oluşan dil yadigarları, yazıldığı devir için Türk dilinin fotoğrafı hükmündedir. Bu eserler, hazırlayanın tercih ettiği dil ile anlatılır. Yazarın verdiği örnekler ise çok zaman iki dil iledir. Ancak bazılarında anlatım iki dil ile, örnekler ise üç, dört hatta bazen beş dil iledir. Çok dilli transkripsiyon metinleri yazıldığı devirde Türk dilinin ve diğer yan dillerin de söz varlığını göstermekte, bu tür eserlerin sadece Türk diline değil eserdeki yan dillere de katkısı olmaktadır. Çok dilli eserlerden sözlüklere örnek, Dictionnaire Français-Arabe-Persan et Turc adlı Alexandre Handjeri'nin kaleme aldığı 1841 tarihli bir eserdir. Çok dilli eserlerden gramerlere örnek, Vocabulaire Oriental, Français-Italien, Arabe, Turc et Grec adlı Victor Letellier'nin kaleme aldığı 1838 tarihli bir eserdir. Çok dilli eserlerden rehberlere örnek, Fransızca adıyla Guide en trois langues: Française, Anglaise et Turque; İngilizce adıla Guide in three languages: French, English and Turkish; Osmanlı Türkçesi adılla Rehber-i elsine-yi selâse: Fransevî ve İngilizî ve Türkî olan eserin müellifi Nassif Mallouf'tur ve 186o tarihli bir eserdir. Çok dilli sözlük, gramer kitapları ve rehberler, günümüzdeki çok dilli sanal çeviri araçlarının eski örnekleri sayılabilir. Çok dilli biçimde hazırlanmış sözlükler, gramer kitapları ve rehberler bu tebliğin araştırma konusu olup özellikleri üzerinde etraflı bilgi sunulacaktır.

Anahtar kelimeler: Transkripsiyon metni, çok dilli sözlük, çok dilli gramer kitabı, çok dilli rehber.

\section{Multilingual works in transcription texts: Dictionaries, grammar books, guides}

\begin{abstract}
Transcription texts have been the primary sources for Turkish vocabulary and pronunciation since Codex Cumanicus. Language heirlooms consisting of grammar books, dictionaries and guides are the photograph of the Turkish language for the period in which it was written. These works are explained in the language preferred by the author. The examples given by the author are mostly with two languages. In some, however, the narration is in two languages, with examples in three, four or even five languages. Multilingual transcription texts show the vocabulary of the Turkish language and other sub-languages at the time of writing, and such works contribute not only to the Turkish language but also to the secondary languages in the work. An example of multilingual dictionaries is an 1841 work by Alexandre Handjeri, Dictionnaire Français-Arabe-Persan et Turc. An example of multi-lingual grammar is an 1838 work by Victor Letellier, Vocabulaire Oriental, Français-Italien, Arabe, Turc et Grec. An example of a multilingual guide is the French guide En trois langues: Française, Anglaise et Turque; English in English: French, English and Turkish; Ottoman Turkish,
\end{abstract}

1 Doç. Dr., Kırklareli Üniversitesi, Fen Edebiyat Fakültesi, Türk Dili ve Edebiyatı Bölümü (Kırklareli, Türkiye), yilmazyakupbey@gmail.com, ORCID ID: oooo-0001-6230-8850 [Makale kayıt tarihi: 11.10.2019-kabul tarihi: 20.11.2019; DOI: 10.29000/rumelide.648425] 
Rehber-i elsine-yi selâse: Nassif Mallouf, the author of the work which is French and English and Turkish, is a work dated 1860. Multilingual dictionaries, grammar books, and guides are old examples of today's multilingual virtual translation tools. Multi-lingual dictionaries, grammar books and guides are the subject of research of this communique and detailed information on its features will be presented.

Keywords: Transcription text, multilingual dictionary, multilingual grammar book, multilingual guide.

\section{Giriş}

Codex Cumanicus'tan bu yana transkripsiyon metni niteliğinde çok sayıda eser kaleme alınmıştır. $\mathrm{Bu}$ eserlerin bir kısmı gramer, bir kısmı sözlük ve kalan kısmı da rehber kitap niteliğindedir.

Batılılar Transkripsiyon metinleriyle Türkçe öğrenmeyi, şu gerekçelerle istemişlerdir (Yılmaz \& Toktar, 2017, s. 1):

1. Osmanlı Devleti veya farklı Türk halklarıyla irtibata geçmek isteyen Avrupa devletlerinin tercümanlarını yetiştirmek.

2. Osmanlı Devleti veya farklı Türk halklarıyla ticari faaliyet içinde bulunan Avrupalı tüccarlara yardımcı olabilmek.

3. Osmanlı Devleti veya farklı Türk halklarının arasında Hristiyanlığı yayması için yetiştirilen misyonerlere Türkçeyi kısa zamanda ve kolayca öğretmek.

4. Osmanlı Devleti veya farklı Türk halklarıyla askeri, siyasi ve diplomatik ilişkileri kolaylaştırmak.

5. Osmanlı Devleti veya farklı Türk halklarıyla irtibata geçmek için kullandıkları Hristiyan ve Musevi tercümanların hilelerinden, aldatmalarından kurtulmak.

6. Rusya gibi kendi sınırları dahilindeki Türk halklarıyla irtibatları kolaylaştırmak ve sağlamlaştırmak.

7. Tamamen ilmi kaygılarla Türkçeyi ve Türk kültürünü tanımak.

Türkçe öğretmeyi hedefleyen gramerler, sözlükler ve rehber kitapları önce tek dil ile yazılmışken, zaman içinde ihtiyaçların değişmesiyle ikinci, üçüncü, dördüncü dillerle birlikte çok dilli gramerler, sözlükler ve rehber kitapları şeklinde ortaya konmaya başlanmıştır.

\section{A. Gramer kitapları}

Gramer ya da dilbilgisi, bir dili ses, kelime yapısı, cümle kuruluşu bakımından inceleyen ve bunlarla ilgili kuralları ortaya koyan bilimdir (Topaloğlu, 1989, s. 56). Gramer kitapları, Hint dil bilgini Panini'nin M. Ö. beşinci asırda kaleme aldı ̆̆ı çalışmalarla görülmeye başlamıştır (Aksan, 1995, s. 16). Sonraki devirlerde hem sistem ve hem de yaklaşım, yöntem ve teknik bakımından sağlam kurgulanmış gramer kitapları hazırlanmıştır. Türkçe için Batı'da hazırlanan ve transkripsiyon metni olarak anılan eserlerde çok dilli sayılan örnekler arasından seçilenler şunlardır: 


\section{Türkçe-Rusça-Fransızca}

Holdermann, J. B. (1776, 1777). Turetskaya Grammatika. Çev. Reinhold Gablitsl. Moskova: İmparatorluk Üniversitesi: Bu eser 1730'da İstanbul'da basılan ve J. B. Holdermann 1694-1730 yılları arasında yaşamış, Galata Saint Benoit misyonunda çalışmış bir Cizvit rahibi- ve İbrahim Müteferrika tarafından hazırlanan Grammaire Turque'ün (Holdermann J. B., 1730) Rusça'ya çevirisidir. Grammaire Turque'ün Turetskaya Grammatika adıyla Rusça'ya iki çevirisi vardır. Birincisi 1776 yılında Petersburg'da (Holdermann J. B., 1776), diğeri 1777 yılında Moskova'da basılmıştır (Yılmaz \& Toktar, 2019, s. 3181).

1776'da Turetskaya Grammatika adıyla Rusçaya çevrilen Holdermann'ın yazdığı Grammaire Turque adlı eser, hem Osmanlı veya Türkiye Türkçesini öğreten ilk kitap hem de Kiril alfabesiyle transkribe edilmiş ilk eser olma özelliği taşır (Yılmaz \& Toktar, 2019, s. 3182).

Küçük Kaynarca'da Türkiye (Osmanlı Devleti) ile yapılan barış antlaşmasından (21 Haziran 1774) sonra Türkiye'ye karşı artan askerî ve siyasi ilginin etkisi ve Moskova Üniversitesine bağlı Akademik Kolej’in öğrencilerine Türk dili hakkında ders kitabı hazırlama ihtiyacı sonucunda Rusça olarak bu dilin ilk gramer kitabı ortaya çıktı: Turetskaya Grammatika ili kratkoy i legçayşiy sposob k izuçeniyu turetskogo yazıka s sobraniem imyen, glagolov i nujneyşih k poznaniyu reçey i mnogih drujeskih razgovorov. Perevedeno s Frantsuzkago v-S-Pb., 1776. İ injenernom şlyahetskom kadetskom korpuse (Türkçenin Grameri veya Türkçeyi öğrenmek için en kısa ve kolay usul - Dili öğrenmek için en gerekli adlar, fiiller ve birçok dostça sohbetler - St. Petersburg'da 1776'da Şlyahta Topçu ve Mühendis Kadet Alayı'nın desteğiyle Fransızcadan çevrilmiştir.) (Kononov, 2009, s. 199). Baskı tarihi 1776 olan eser 3+288+7 sayfa halinde Petersburg'da 1200 adet olarak yayımlanmıştır (Kononov, 2009, s. 200-201).

Bir sene sonra 1777'de Moskova'da aynı gramer kitabının yeni baskısı yayımlanır ve bunda çevirenin adı gösterilir: Reinhold Gablitsl (Рейнголдом Габлитслем) (Kononov, 2009, s. 199). 1777'de yapılan ikinci baskının ön sözünde tercüman Reinhold Gablitsl bu gramerin yayımlanmasının amacı hakkında "Türkiye ile Rusya arasında yapılan şerefli barış antlaşmasından yararlanan Moskova Üniversitesi, vatana hizmet amaciyla, Karadeniz'de serbest ticarete imkân bulunduğunu göz önüne alarak, gençlerin Türkçe öğrenmeleri için faydalı olan Türkçe kitaplar elde etti. Lakin herhangi bir dili, onun gramer kurallarını bilmeden öğrenmenin imkânsız olduğunu bilen Moskova Üniversitesi, Fransızca yazılmış bu Türkçe grameri Rusçaya çevirmeyi bir görev bildi ve bu işi bana, kendi mezununa bıraktı." ifadelerini kullanır (Kononov, 2009, s. 200). Eser 1777 ylında Moskova'da İmparatorluk Üniversitesi tarafından üniversite öğrencileri için Turetskaya Grammatika adıyla Moskova'da $3+585$ sayfa halinde basılmıştır (Holdermann J. B., 1777, s. 1).

Eser yedi ana bölümden ibarettir: 1. imlâ 2. isimler ve zamirler 3. fiil 4. konuşmanın diğer bölümleri 5. söz dizimi 6. isim ve fiil derlemesi 7. hayatın her safhasında sıkça kullanılan ifadelerin yer aldığı yirmi farklı diyalog.

Grammaire Turque, zaman içinde pek çok yere yayllmış, başta dijital kütüphaneler olmak üzere eski yeni pek çok katalogda ve kayıtta kendine yer edinmiştir. Eserin Rusça çevirisi olan Turetskaya Grammatika da Rusya Milli Kütüphanesinde yerini almıştır: 1776 Tarihli Baskı Shelf Number: 18.90.5.36 138/302; Barcode: 9671606-10. 1777 Tarihli baskı Shelf Number: 18.79.3.74 139/979; Barcode: 9671607-10. 


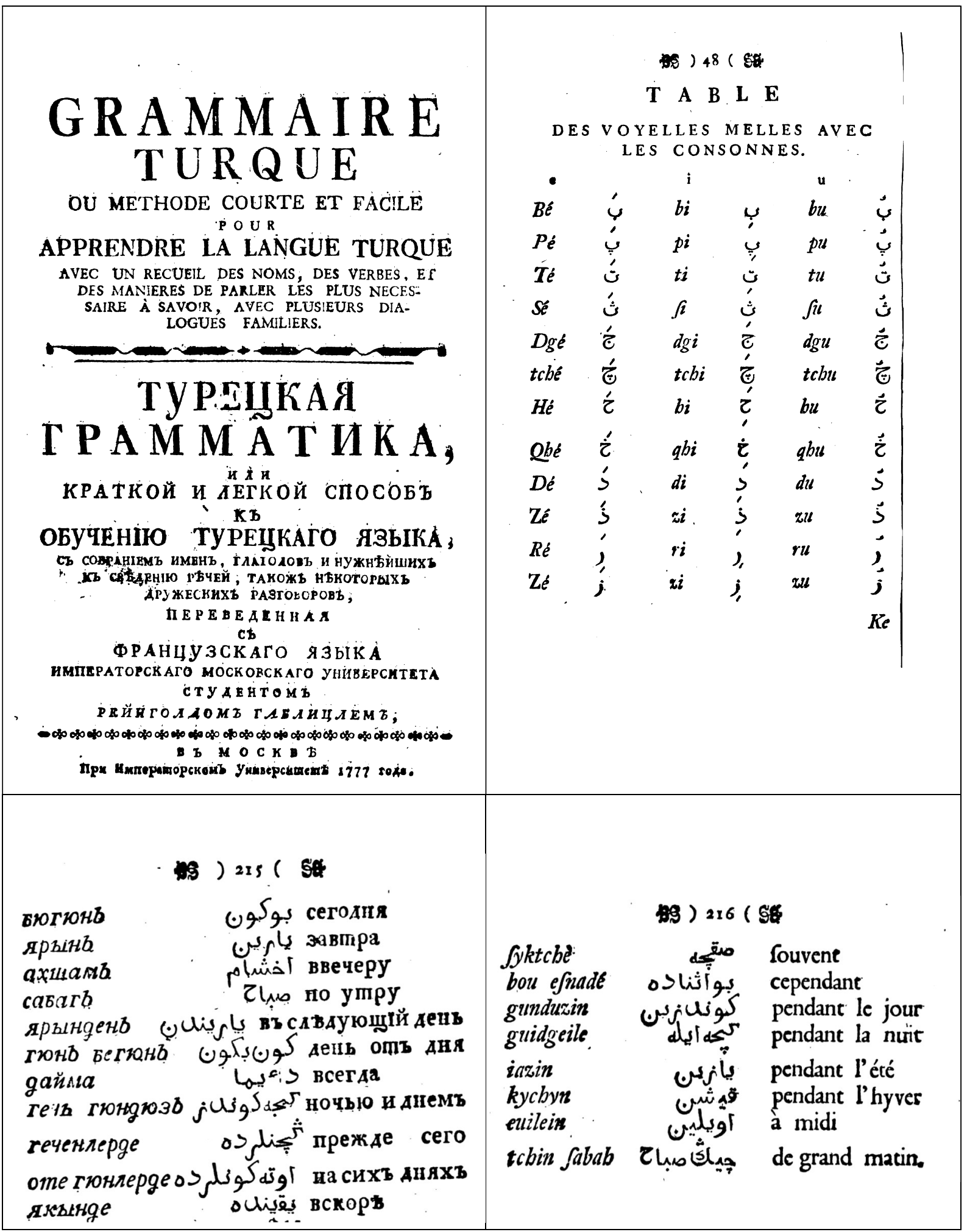




\section{Fransızca-İtalyanca-Arapça-Türkçe-Yunanca}

Letellier, Victor (1838). Vocabulaire Oriental, Français-Italien, Arabe, Turc et Grec Pour la Seule Prononociation. Paris: Guyot et Scribe, Barrois, et Dondey-Dupre: Beş dilli sözlüğe en güzel örnek bu eserdir. Burada Arapça ve Yunancayla beraber Türkçeyi Fransız ve İtalyanlara öğretmek gaye edinilmiştir (Yılmaz \& Özkaya, 2017, s. 576). Üzerine şimdiye kadar tespit edebildiğimiz herhangi bir çalışmanın mevcut olmadığı Vocabulaire Oriental, Français-Italien, Arabe, Turc et Grec Victor Letellier'nin kaleme aldığı bir eserdir. Bu eser poliglot yani çok dilli bir sözlüktür. Fransızca ve İtalyanca merkezli iki dilin karşılığında içinde Türkçe, Arapça ve Yunanca karşılıklar vardır.

Eserin açıklama ve gramer kısımları 2 sütun hâlinde olup sözlük kısmı dört sütundan ibarettir. Birinci sütunda Fransızca ve İtalyanca kelimeler asıllarıyla yazılmıştır. İkinci sütunda Arapça kelimeler Fransız alfabesiyle transkripsiyonlu olarak yazılmıştır. Üçüncü sütunda Türkçe kelimeler Fransız alfabesiyle transkripsiyonlu olarak yazılmıştır. Dördüncü sütunda Grekçe kelimeler Fransız alfabesiyle transkripsiyonlu olarak yazılmıştır.

Eserin yazıldığı hedef kitle de yazar adının altında belirtilmiştir. Buna göre bu eser Afrika'daki Fransız ordularına, denizlerdeki askerlere, Cezayir, Türkiye ve Yunanistan genelindeki Fransız casuslara yaraması için yazılmıştır (Letellier, 1838).

Eserin ön sözünde ise şu ifadelerle eserin yazılış amacı belirtilmiştir: "Bu kitabı, gezginlerin ilk ihtiyaçlarını karşılaması ve gezginlerin dillere az da olsa yakınlık duyması (tanıması) niyetiyle oluşturdum. Bu kitabı ne bir dilbilimci ne de bir oryantalist için tasarladım, onlar için tasarlasaydım daha çok bilimsel bir alana hitap edecekti. Kesinlikle bu çalışma bilim açısından daha az faydalıdır, benim amacım bilim yapma kaygısı taşımadan sadece bir hizmet sunmak oldu. Böylece hem unutulmaya yüz tutmuş dillerin öğrenimini kolaylaştırmış olacağım, hem de bu işi bir eğlence olarak görmeden yapmış olacağım. Önemli olan en çok ihtiyaç duyulan ve kullanılan kelimelerin ve cümlelerin anlaşılmasına yardımcı olmaktır. Bu, büyük düzeltmeler içeren bir telaffuz transkripsiyonudur. Böylece öğrenme hedefindeki dil daha kolay anlaşılabilecektir. Tüm bunlara rağmen, bu yazılanları kibir duygusundan tamamen arınarak kendi bilincimle uyguladım; zira doğanın bir çalışması olacaksa, bu çalışma büyük bir farkındalık ile yazılırsa yazarına zafer getirecektir, aksi hâlde kurak, verimsiz bir çalışma haline dönüşecektir.” (Letellier, 1848, s. V-VIII).

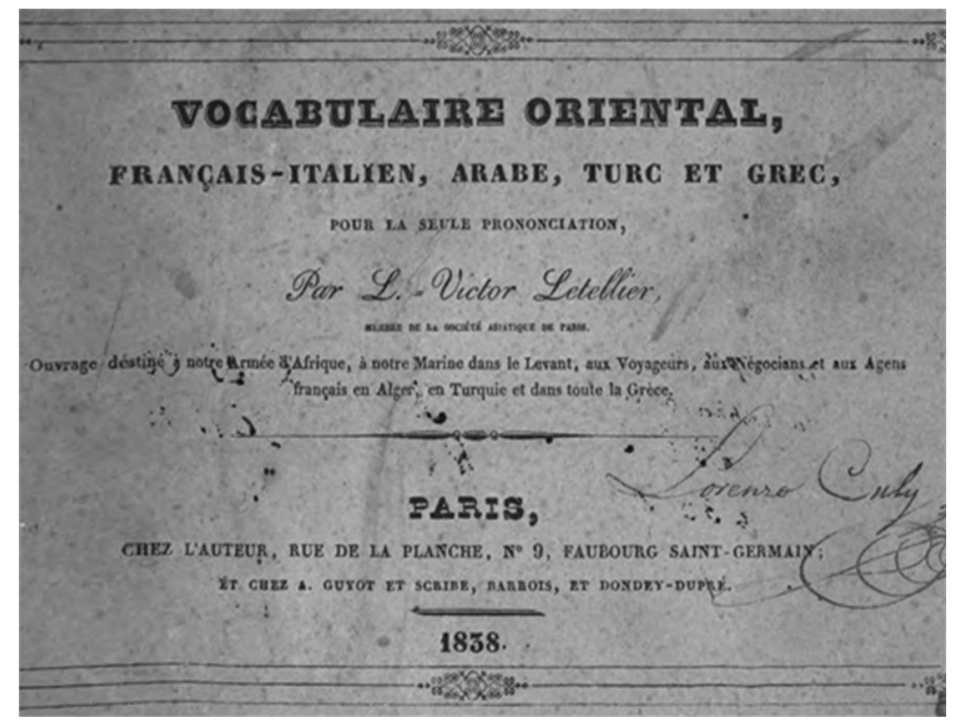




\begin{tabular}{|c|c|c|c|}
\hline PRANGAIS-ITALIEN. & ARABE. & TURC. & GREC. \\
\hline 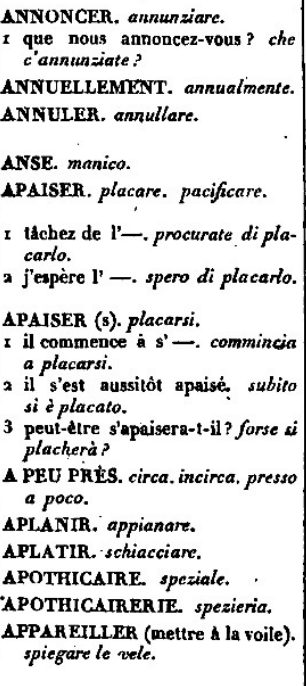 & 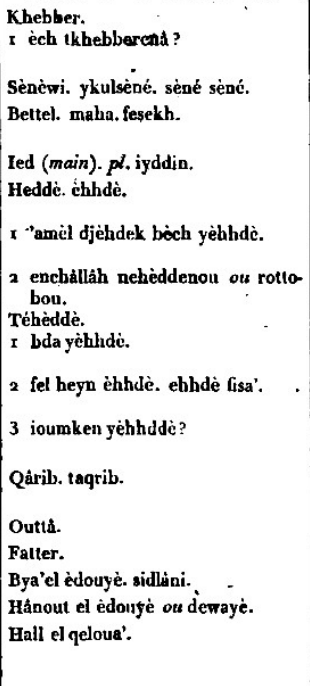 & 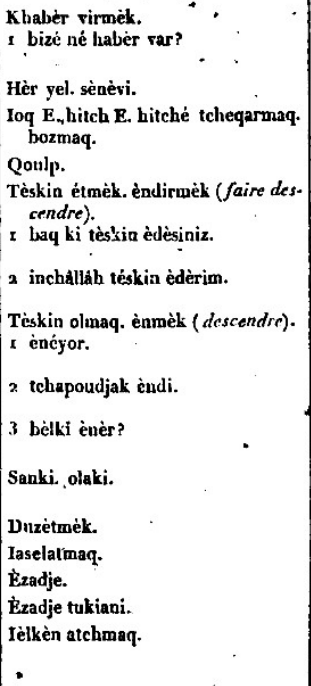 & 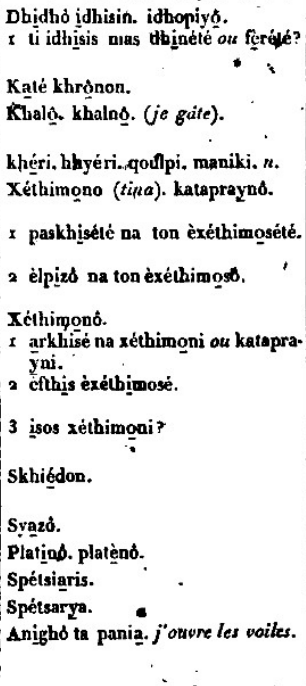 \\
\hline
\end{tabular}

\section{Fransızca-Türkçe-Macarca}

Charles de Besse, Jean (1829). Abrégé de la Grammaire Turque Contenant Outre le Principe de Cette Langue, des Idiotismes, des Dicours Familiers et un Petit Vocabulaire en Français, Turc et Hongrois. Pest: Otto Wigand: Yılmaz ve Aksoy'un tanıtma yazısında şu bilgiler yer alır (2019): Besse'nin 1829'da kaleme aldığ Abrégé de la Grammaire Turque Contenant Outre le Principe de Cette Langue, des Idiotismes, des Dicours Familiers et un Petit Vocabulaire en Français, Turc et Hongrois adlı eser üç dilli olup Fransızca, Türkçe ve Macarcadır. Fransızca kanalıyla Türkçe ve Macarcayı öğretmek hedeflenmiştir. 1829 ve 1830 tarihlerinde Ermenistan, Gürcistan, Anadolu ve Kırım gezilerini anlattığı Voyage en Crimee au Cavcase (De Besse, 1838) adlı eserin de sahibi olan Besse'nin tam adı Jean Charles de Besse olup Macarcadaki şekli Janos Karoly Besha'dır. 1765'te doğduğu kayitlarda geçer (Parastatov \& Kondrasheva, 2018, s. 328). Besse, bu eserinden anlaşıldığı kadarıyla, Türk dünyasını, coğrafyalarını gezen, etnik unsurları ve onların kültürlerini iyi tanıyan, dillerini iyi bilen bir kişidir. Ayrıca Macarların tarih ve kültürlerine dair araştırmalar da yapmaktadır. Bu eseriyle geziden beklediklerini etraflıca ortaya koymuştur. Besse, gramerin ön sözünde ifade ettiğine göre, Doğu Hint adalarına uzun soluklu bir gezi düzenlemiş, burada kendini Farsça öğrenmeye hasretmiş, İstanbul'a geldiğinde ise yalnızca Türkçe ve Yunanca konuşulan bir eve yerleşmiş, ayrıca kendisine bir yıl boyunca yazı ve Türkçe öğreten çok iyi bir molla bulmuştur. 1825'te İstanbul'da bulunmuş ve Türkçesi mükemmelleşmeye başlamıştır. Daha sonra da Türkiye'nin doğu taraflarına yaptığı gezinin hazırlamakta olduğu gramer kitabını yayımlanmasını geciktirdiğini yazar (Besse, 1829, s. VI).

Besse, eserini İstanbul'da, öncelikle Almanca olarak hazırladığını belirtir. Tam adı Abrégé de la Grammaire Turque Contenant Outre le Principe de Cette Langue, des Idiotismes, des Dicours Familiers et un Petit Vocabulaire en Français, Turc et Hongrois olan Türkçe gramer kitabı şu özelliklerden ibarettir:

Kitabın bölümleri şöyledir: Dış kapak: Ebru renginde bir dış kapak mevcuttur. I. sayfada ilk iç kapak vardır ve burada Gramaire Turque ibaresi mevcuttur. III. sayfada ikinci iç kapakta eserin adı Abrégé de la Grammaire Turque Contenant Outre le Principe de Cette Langue, des Idiotismes, des Dicours 
Familiers et un Petit Vocabulaire en Français, Turc et Hongrois; eserin müellifinin Fransizca biçimiyle adı Jean Ch[arles] de Besse; eserin yayımlandığı şehir Pest (Peşte); yayınevi adı Otto Wigand ve adresi Rue de Waitzen; eserin yayın tarihi 1829 olarak geçer. IV. sayfada ilk iç kapak arkasında Latince "Haec mala sunt equidem: fac meliora, precor" ifadesi yazılıdır ki anlamı "Bunlar gerçekten kötüdür, daha iyi olması için dua edelim.” şeklinde olmalıdır. V. sayfada Avant-propos adıyla ön söz verilmiş, ön sözde bu kitabın Türkçenin ilkelerini öğrenmek isteyenlere bu dilin kavram ve kelimelerini vermeyi, bir bilen olmaksızın telaffuzu öğretmeyi, Türkçenin çekimlerdeki ince detaylarını öğretmeyi amaçladığını belirtir. Devamında Macarcanın Türkçeye yakınlığına, Latin alfabesini kullanan Macarların alfabe karakterlerinin Türkçenin kullanımına da uygun olduğuna, Macarlar dışındaki Avrupalı yabancıların bir saatte harflerin telaffuzuna vâkıf olacaklarına; Türkçe kelimeleri akıcı bir şekilde okuyabilmek için Latince karakterleri benimsemenin gerekli olduğuna, doğu seferine, Farsça merakına ve Türkçe öğrenmek için teşebbüslerine değinir. Ardından da Türkçenin öğrenilmesinden, Türkiye'nin ve özellikle İstanbul'da boğazın her iki yakasındaki güzelliklerin tanınmasından kaynaklı olarak kendisine duyulacak minnettarlığı hatırlatır. Ön sözün sonunda da Budapeşte, 5 Ocak 1829 tarihi kayıtlıdır. VIIVIII. sayfada İçindekiler kısmı vardır.

1. Bölümde (1-7. s.) alfabe ve telaffuz, Türk alfabesi, okuma örnekleri yer alır. Alfabede harf sayısı 35 olarak geçer. Ayrıca her transkripsiyon metninde olduğu gibi bu eserde de alfabe listesi ve karşılıkları sunulmuştur. 2. Bölümde (7. s.) konuşmanın bölümleri başlığı altında kelime türleri sıralanmıştır. Bunlar adlar, zamirler, fiiller, sıfat-fiiller, takılar, zarflar, bağlaçlardır. Diğer bölümlerde bu kelime türleri etraflıca anlatılmıştır. Önce Türkçesi, ortada Fransızcası ve sonda da Macarcası verilmiş ve üç dilli gramer kitabı olarak karşılıklı bir öğrenme-öğretme yolu benimsenmiştir. 3. Bölüm (7-8. s.) adları; 4. Bölüm (8-10. s.) sıfatları; 5. Bölüm (10-12. s.) sayıları; 6. Bölüm (12-17. s.) zamirleri; 7. Bölüm (17-19. s.) fiilleri, 8. Bölüm (19-46. s.) yardımcı fiilleri, 9. Bölüm (46-47. s.) sıfat fiilleri, 10. Bölüm (47-49. s.) takıları, 11. Bölüm (49-53. s.) zarfları, 12. Bölüm (53. s.) bağlaçları, 13. Bölüm (53-54. s.) ünlemleri, 14. Bölüm (54-143. s.): (54-59. s.) En geniş bölüm söz dizimi kısmıdır. Öncelikle Türkçe yapının kuruluşu başlığı altında 31 maddeyle cümle kuruluşu anlatılır. (6o-67. s.) Türkçe idyotizmler başlı̆̆ıyla ilişki sözleri, deyimler, mecaz anlamlı kelimeler ve atasözleri verilmiştir. (67-90. s.) Bilindik konuşmalar başlı̆̆yla Türkiye'de canlı olan ve sık kullanılan diyalog cümleleri verilmiş̧ir. Bunlar kendi içinde kullanıldıkları yere göre sınıflandırılmıştır: I. Bir dost selamlama içün, II. Devamı, III. Çuha satın almak içün, IV. Yol üzre, V. Konak üzre, VI. Konakçı ile hisab görmek içün, VII. Haber üzerine, VIII. Aga ile hizmetkâr, IX. Avdan ötürü, X. Kahvaltı üzre, XI. Bahçe üzerine, XII. Oyun üzre, XIII. Seyr üzre, XIV: Seferden üzre, XV. Birinden sual etmek içün, XVI. Yazmak üzerine başlıklarıyla diyaloglar vardır. (9092. s.) Bazı ülke ve şehirlerin isimleri başlığıyla kıta, ülke, bölge, deniz, şehir, kasaba ve köy adları verilmiştir. Bu adlar, kayıtlı şehirlerin adlarının değişikliğini takip etmek için de önemli birer veridir. (92-93. s.) Bazı millet adları bahsinde de millet ve bir bölge halkı adı verilmiştir. (93. s.) Nehir adları, dağ adları vardır. (94. s.) Semavi ve ruhi şeylerin adları, anasır-ı erbaa denilen hava, ateş, toprak ve su vardır. (95. s.) Genel olarak dünyada görülen hava olayları, (95-96. s.) mevsim ve zaman adları, (96. s.) haftanın günleri yer alır. (96-98. s.) Sultan Mahmud'un iç mahkemesinin büyük memurları başlığıyla mahkemede görevli memuriyet adları sıralanmıştır: Hasodabaşı, silahdar, çuhadar... (98-143. s.). Fransızca, Türkçe ve Macarca söz varlığının bulunduğu sözlük kısmı 1778 kelimeden ibarettir. (143-170. s.) Türkçe, Fransızca ve Macarca sırayla verilen sözlük de 1089 kelimeden ibarettir. (171-172. s.) 


\section{A B R É G $\mathbf{E}$ DE $\mathbf{L}$ A \\ GRAMMÁIRE TURQUE, C ONTENANT, \\ OUTRE LES PRINCIPES DE CET'TE LANGŨE, DES IDIOTISMES, DES DISCOURS FAMILIERS,

\author{
E $\mathbf{T}$
} \\ U $\mathbf{N}$ P $\mathbf{E}$ T $\mathbf{T}$ I $\mathbf{T}$ \\ V O C A B U L A I R E}

EN FRA NGAIS, TURCET HONGROIS.

$$
\mathbf{P} \boldsymbol{A} \mathbf{R}
$$

JEAN CHs. DE BESSE.

P E S T.

OTH O-N WIGAND, RUE DE WAITZEN.

1829. 


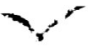

Français. $\quad \therefore$ Turc. Hongrois.

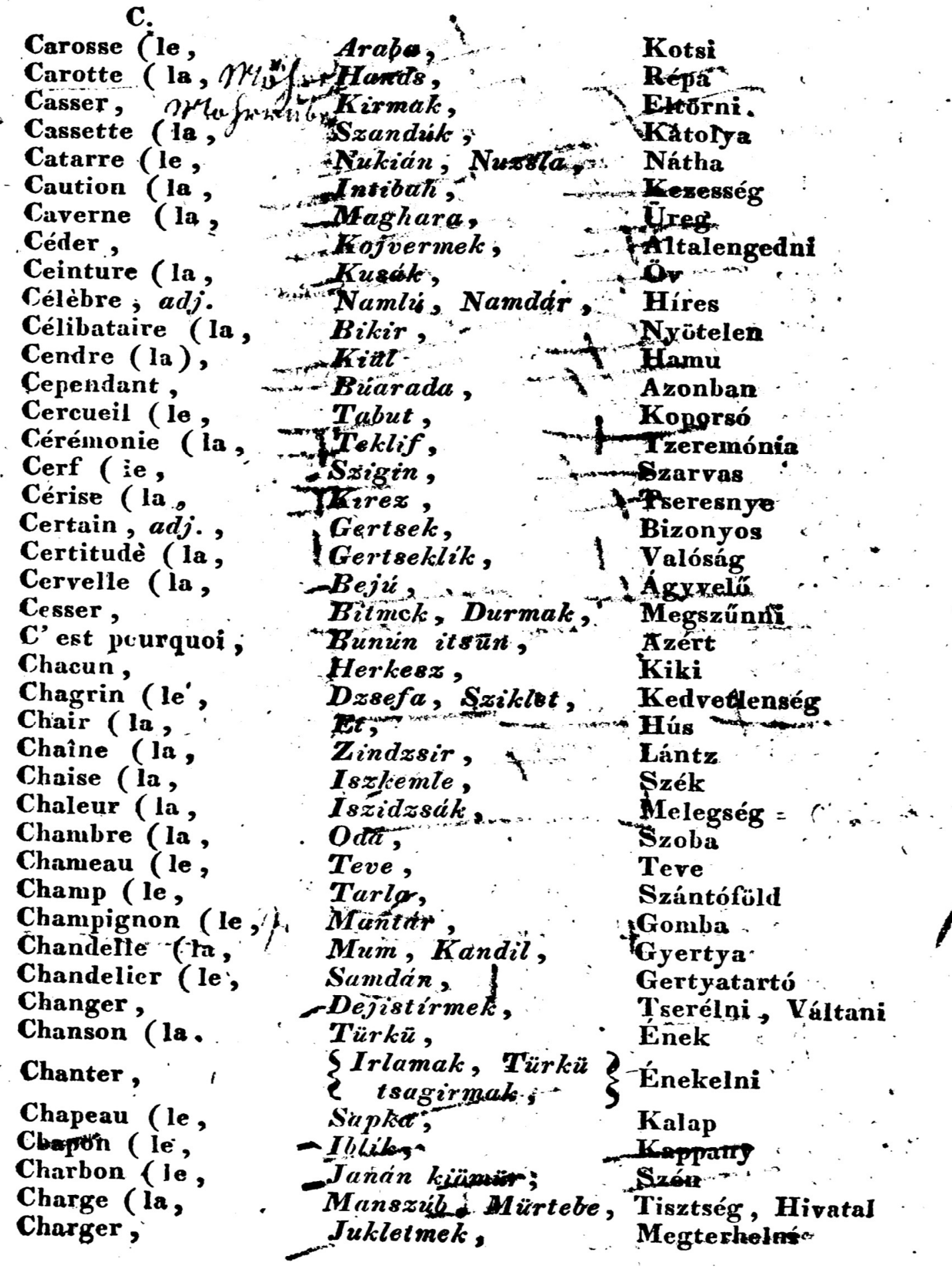


Ayrıca şu gramerler de örnek olarak sunulabilir:

\section{Türkçe-Fransızca-İngilizce}

Schroeder, Guillaume (1835). Grammaire Turque a l'Usage des Français et Anglais. Leipsic: Otron Wigand: Eser Fransızca ve İngilizce anlatımlıdır. 53. sayfaya dek gramer, 53. sayfadan 77. sayfaya dek idyotizm başlığıyla konuşma dilindeki kalıp diyalog cümleleri, 77. sayfadan 84. sayfaya dek özel adlar ve bazı resmi terimler, 84. sayfadan 142. sayfaya dek de üç dilli (Türkçe, Fransızca ve İngilizce) sözlük yer alır.

Medigi, Le P. Minas (1844). Grammaire Polyglotte. Venise: Imprimerie Arménienne de S. Lazare: Ermenice anlatımla, Ermeni milletinin Arapça, Farsça, Türkçe, Fransızca ve Rusça öğrenmesi amacıyla hazırlanmış çok dilli bir gramer kitabıdır.

Ludwig, Albert (1853). Grammaire Turque a l'Usage des Français, Anglais et Allemands avec un Dictionnaire Français-Turc. Leipsic: Otto Wigand: Eser Fransızca anlatımlıdır. 1-119 arasında gramatik açıllamalar, 120-129 arasında idyotizmler, 130-169 arasında diyaloglar, 170-183 arasında özel adlar ve terimler, 184-326 arasında Fransızca-Türkçe sözlük bulunur. 327'de Errata kısmıyla eser tamamlanır.

\section{B. Sözlükler}

Sözlükleri ele aldığı dil sayısı bakımından iki kısımda ele almak mümkündür: Tek dilli sözlükler, çok dilli sözlükler (Aksan, 1995, s. 400). Bu eserler çok dilli sözlüklere girer. Madde başı karşılığı olarak en az üç dil yer alır. Poliglot yani çok dilli bir sözlük olan bu eserler tam olarak Letellier'nin adlandırmasına göre quintiglotte, yani beş dilli bir sözlük hüviyetindedir (Letellier, 1848).

\section{Fransızca-Türkçe-İtalyanca}

Mehmet Atuf (h. 1285, m. 1868). Dictionnaire Français-Turc-Italien. Constantinople: Imprimerie du Djeridei-Havadis: İBB Atatürk Kitaplığ 1 M. Cevdet Koleksiyonu 1857 numarada kayıtlı olan eser Fransızca, Türkçe, İtalyanca olmak üzere üç dilli, iç kapağı sağda, başlangıcı solda, Latin alfabesi esaslı, transkripsiyon metni özelliği taşıyan bir sözlüktür. Esas aldığımız kayda göre ilk dört sayfa eserin mukaddimesi ve künyesine ayrılmıştır. Öncelikle Fransızca olarak Preface (ön söz) sayfası, sonra da Osmanlı Türkçesiyle Mukaddime mevcuttur. Mukaddimede Selanikli Mehmed 'Āṭuf imzalı şu ifadeler geçer (Atuf, 1868):

"Şimdiye degin neşr olunmuş olan bu yolda lugiat kitāblarından bu kitāb daha ziyāde mükemmel olup ecnebī lisānlarının taḥ̣ịiline ārzū-keş ve heves-kār bulunan zevāt-ı macārif-simātıñ piş-i naẓar-ı diḳkatine nihāde èderiz. Elsine-yi mezbūreyi taḥṣil eylemek ve her bir lugatiñ 'aynı ma'nāsını fehm ètmek isteyenlere ümìd èderim ki bu te'lif-i ‘ācizānemde gāayet sa'y ü vaḳt ètmiş olduğum terceme-yi 'aynīsi büyük istimdād èdecek ve bu te'līfimiziñ ḳırā’atine rag̈bet buyuracak zevāt-ı hamiyyet-simāt bu lugat kitābında kendilerine müfīd lugatler ve iżāhātlar bulacaḳdır ve Türkçe ma'nālarına geldikde z̧ann èderim ki bu yolda kitāblarda mümkin olduğu mertebe açı̣ șūretde yazılmışdır. Binā’en 'aleyh bu kitābıñ birinci def‘a țab`ı temenní ètdigim rag̉beti bulup şimdiki ḥālde te'lifiyle meşgūl olduguum sā'ir bir şāyān-ı ḳıā’at bir kitāb nezd-i 'ācizānemizde bir teşvikāât 'add olunacaḳdır. Evvel ḥālde te'lïf-i çākerānemizde hüusne muḳtedir olmayaraḳ bulunan noḳsānāta bizlerden daha ziyāde mađūmāt-ı berkemālī ile me’lūf olan ve ḳıāaatine rag̉bet buyuracaḳ żevātıñ 'afv u ḥużūrlarını ‘ācizāne ictisār èderim.” 
Sonraki sayfada kitabın künyesine yer verilmiştir. En üstte Osmanlı Türkçesiyle "Türkçe ve Fransızca ve İtalyanca lisānı üzere tertīb olunmuş lugatdir.” ifadesi, altında eser adı olarak Dictionnaire FrançaisTurc-Italien ve altında Latin harfleriyle müellif adı olarak Mehmet Atuf mevcuttur. Yine Osmanlı Türkçesiyle Mehmed 'Āṭ̂f Beg'iñ telīifi olup Dersa'adet'de Rūz-nāme-yi Cerīde-yi Ḥavādis mațba'asında țab`olunmuşdur." ifadesi, altında sene (H.) 1285 (M. 1868) tarihi, altında Constantinople (İstanbul), altında Imprimerie du Djeridei-Havadis (Cerîde-yi Havâdis Matbaası), altında da 1868 yılı bulunmaktadır.

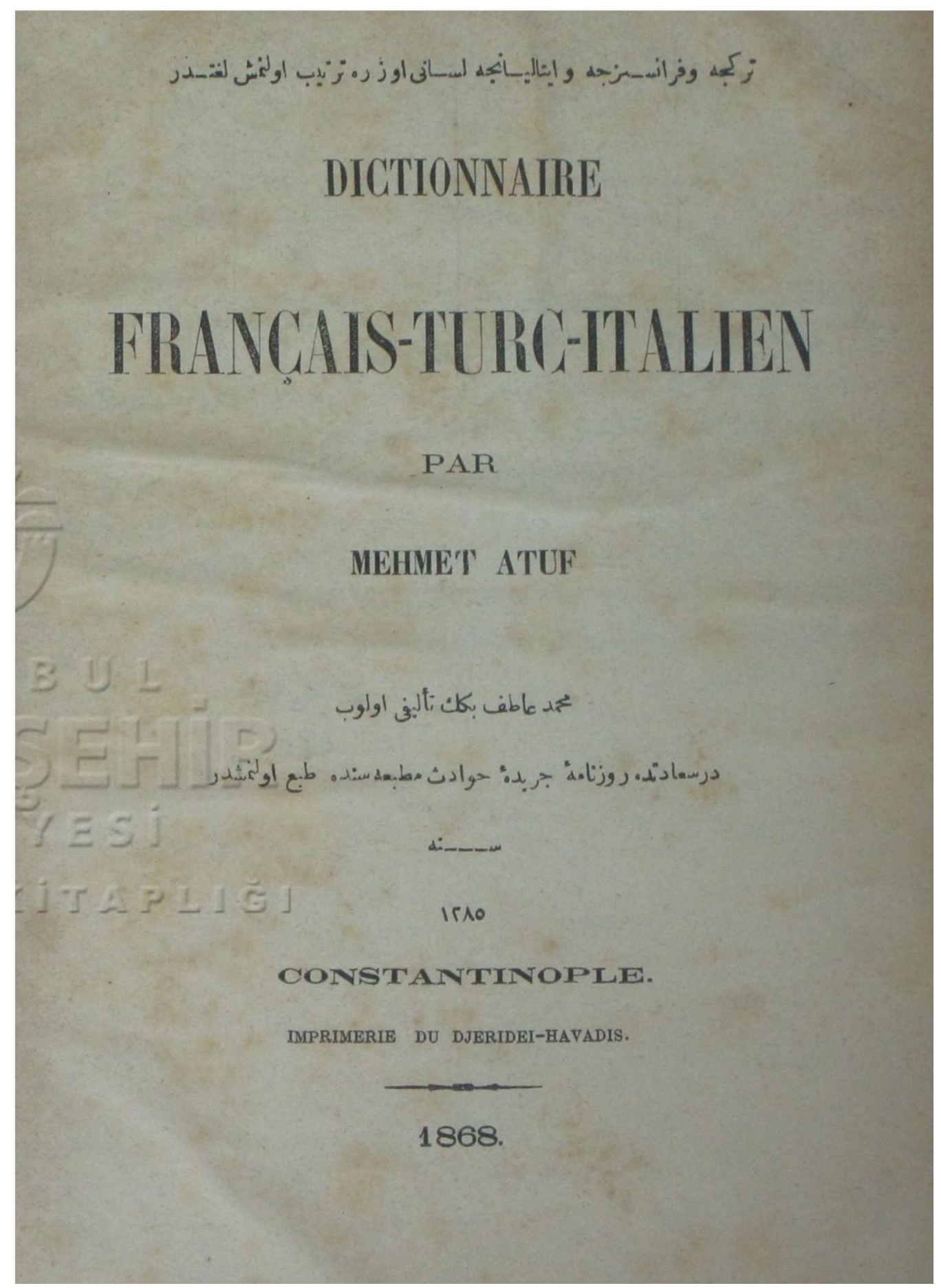


5-408. sayfalar arasında toplam 403 sayfada 12000 civarında kelimenin yer aldığı sözlükte ilk sütun Fransızcaya, ikinci sütun Latin harfleriyle yazılmış Türkçeye, üçüncü sütun Osmanlı Türkçesine ve dördüncü sütun İtalyancaya tahsis edilmiştir. Madde başlarının sayfalara dağılımı şöyledir: A (6. s.), B (26. s.), C (40. s.), D (79. s.), E (108. s.), F (136. s.), G (150. s.), H (160. s.), I (170. s.), J (191. s.), K (194. s.), L (195. s.), M (208. s.), N (235. s.), O (242. s.), P (251. s.), Q (297. s.), R (299. s.), S (334. s.), T (370. s.), U (393. s.), V (394. s.), X, Y, Z (407. s.).

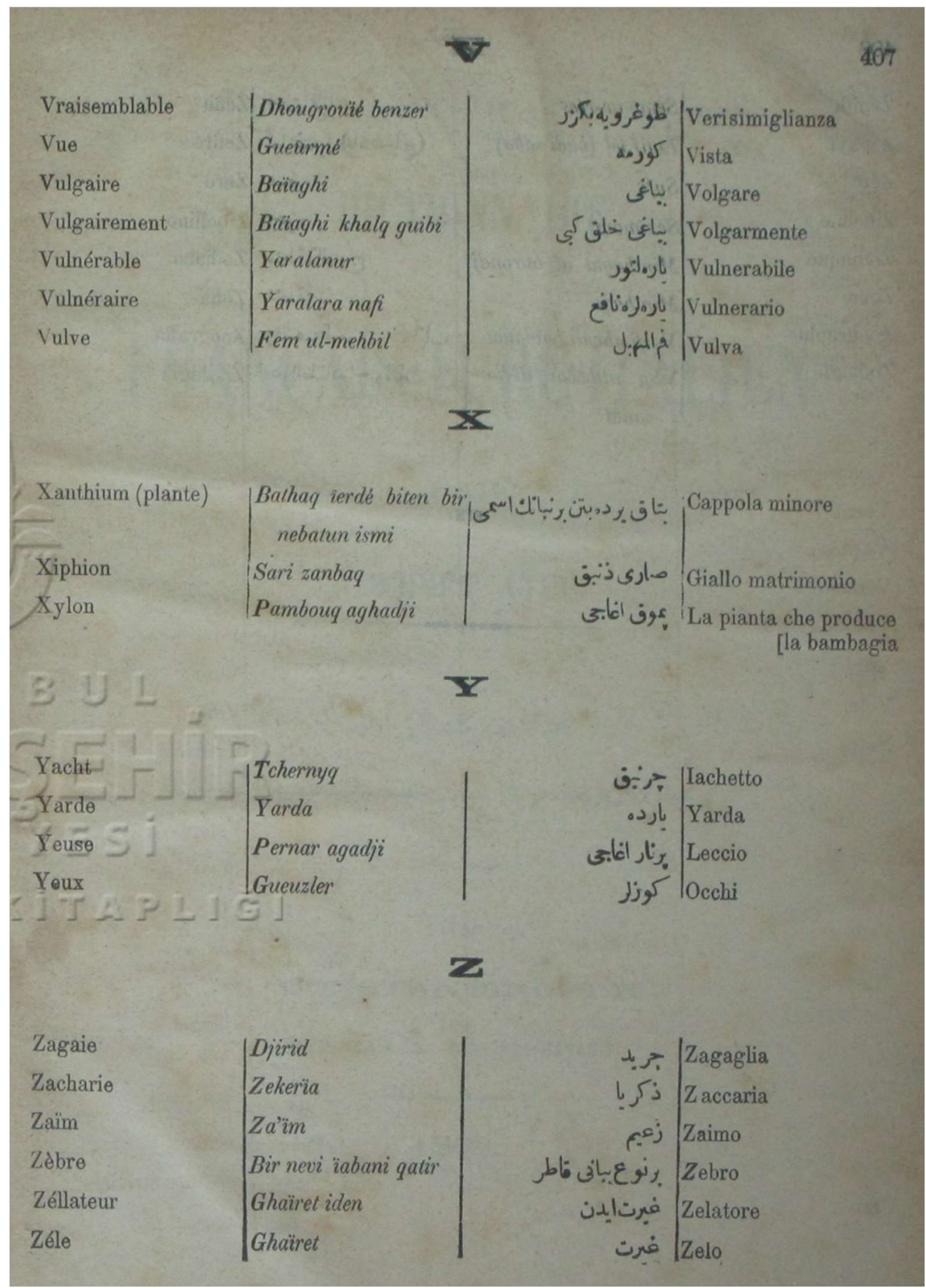




\section{Fransızca-Arapça-Farsça-Türkçe}

Handjeri, Alexandre (1. c. 1840; 2. ve 3. c. 1841). Français-Arabe-Persan et Turc, Tome Premiere. Moscou: De L'Imprimerie de L'Université Impériale: Üç ayrı cilt olarak basılmıştır. Birinci cilt 1840, kalan iki cilt 1841 tarihlidir. Madde başları Fransızca, açılamalar ise Arapça, Farsça, Türkçedir.

\section{Türkçe-Almanca-Macarca-Çekçe}

Korabinsky, Johann Matthias (1788). Versuch eines kleinen Türkischen Wörterbuchs mit beigesetzten deutsch ungrisch und böhmischen Bedeutungen, und einer kurzgefatsten türkischen Sprachlehre. Çek Cumhuriyeti'nin Moravya eyaletinin başkenti Brünn'deki şehir kütüphanesinde 47658 numarada kayıtlıdır. Eserin yazarı Johann Matthias Korabinskydir (1740-1811). Birinci bölümde (162 sayfa) Türkçe, Almanca, Macarca ve Çekçe çok dilli bir sözlük, ikinci bölümde ise (78 sayfa) Türkçenin Almanca açılamalı kısa bir grameri yer almaktadır. Ayrıca eserin baş tarafında yazarın okuyucuya yazmış olduğu kısa bir bölüm mevcuttur (Bekar, 2016, s. 20).

\section{Rehber kitaplar}

Devletler ve halklar arasındaki yakınlaşma, beraberinde birbirlerinin dillerini öğrenmeyi de getirmektedir. Ortak yürütülen projeler, savaşlar anlaşmayı gerektirdiği için bu ihtiyacı kısa sürede karşılayacak dil rehber kitapları hazırlanmıştır. Bu anlamda transkripsiyon metni çizgisinde yer alan ve çok dilli olan rehber kitaplar da hazırlanmıştır. Dil rehber kitabı olarak hazırlanan kitapların hedef dilleri çoklukla Fransızca, bunun yanında İngilizce ve Almanca olmuştur.

\section{Fransızca-İngilizce-Türkçe}

Nassif Mallof (1860). Rehber-i elsine-yi selâse: Fransevî ve İngilizî ve Türkî. Paris: Maisonneuve et C. Libraires-Editeurs: Eserin müellifi, şarktan çılkmış iyi bir şarkiyatçı Nassif Mallouftur. Eserinin başında kendisine ait takdimde şöyle geçer: Doğu dilleri profesörü; İstanbul Saltanat Bilimler Akademisi, Londra Kraliyet Asya Topluluğu ve Paris Asya Topluluğu tarafından takdir edilen sayısız eserin yazarı, Mecidiye madalyalı, askeri tercüman (Mallouf, 1860, s. III). Nassif Mallouf, Lübnan'da bir köy olan Zabbougha'da 20 Mart 1823'te doğmuş, Yaşadığı bölgede eğitim almış. Ardından Yuhanna Aractingi adlı bir tüccar vasıtasıyla 19 Mayıs 1843’te İzmir'deki Fransız propaganda okuluna geldi. 1844'te İzmir Hristiyan Doktrin Kardeşleri Okuluna girdi. Fransızca ve Türkçeyi burada edindi. Yanında İtalyanca, İngilizce, Modern Yunancayı da öğrendi. 1849'da Avrupa'da ve doğuda çok satılan, meşhur Dictionnaire de poche français-turc ou trésor de la conversation adlı sözlüğü hazırlar. 1850'de Abdülmecid'e kitaplarını takdim etti. 1851'de Encümen-i Daniş'e kabul edildi. 17 Haziran 1854'te Paris'te bulunan Société Asiatique üyesi oldu. 1856 'da Nassif Mallouf Mecidiye nişaniyla ödüllendirildi (Malouf Samaha, 2010, s. 22). Kırım Savaşı esnasında, sonrasında Avrupa'da çok hizmeti geçen Nassif Mallouf çok sayıda eser bıraktı ve 16 Mayıs 1865 tarihinde İzmir yakınlarında bulunan Köklüce köyünde vefat etti. Öldüğünde 42 yaşındaydı. İzmir'de Lazaristler Kilisesinde bir mezara gömüldü (Malouf Samaha, 2010, s. 55).

Yllmaz ve Doğan'ın tanıtmasına göre bu kitap (2019, s. 98-103), Fransızca, İngilizce ve Türkçeyi bir arada sunan önemli bir müellifin önemli bir dil rehber kitabıdır. Dil öğrenmede rehber kitaplar, pratik kullanımlar için önemlidir. Eser, en sık kullanılan kelimeleri barındırır. Gramer ve sözlük kullanmak 
yerine daha kolay ve faydalı diyaloglar sunulmuştur. Diyaloglarda kelime ve cümle beraber yer alır. Böylece öğrenmek yerinde ve kolay olur. Üç dilli bir rehber kitabı olması hasebiyle kitaba üç dilden de ayrı ayrı ad verilmiştir. Bu adlar, Fransızcada Guide en trois langues: Française, Anglaise et Turque'tür; İngilizcede Guide in three languages: French, English and Turkish'tir; Osmanlı Türkçesinde Rehber-i elsine-yi selâse: Fransevî ve İngilizî ve Türkî'dir.

İçindekiler şöyle biçimlendirilmiştir: 1. kısımda söz varlığı [170 en gerekli kelime 2. s., İsim-fiiller 26. s., asıl sayılar 30. s., sıra sayılar 36. s., haftanın günleri 38. s., yllın ayları 38. s., renkler 40. s., mevsimler 41. s., zamirler 43. s.], söz varlı̆̆ı sıralamasında önce Fransızca kelimeler, sağında İngilizce kelimeler ve sonraki sayfada Türkçe kelimeler mevcuttur. Eser bir rehber kitap olmasına rağmen kelimelerin altında gramatik açıllamalar yer alır; 2. kısımda ibareler, ifadeler [120 kolay ibare 44. s., 50 zor ibare 60. s.]; 3. kısımda diyaloglar [i̇lk görüşme 72. s., sabahleyin kalkınca - hava 78. s., İngilizce üzerine 90. s., Fransızca üzerine 98. s., zaman 106. s., yaş 110. s., Türkiye'ye seyahat üzerine 114. s., haberler 122. s., kayıkla gitmek üzerine 126. s., akşam yemeği 132. s., hotel 140. s., kahvehanede 144. s., gezi 148. s., ziyaret 152. s., konaklama 160. s., demiryoluyla yolculuk 164. s.]; 4. kısımda 21 adet atasözü; 5 . kısımda eserde tercih edilen telaffuz üzerine bir açıklama mevcuttur. Buna göre bu eserde, en doğru ve uygun olarak Türkçenin Fransızca telaffuzunun benimsendiği ifade edilir.

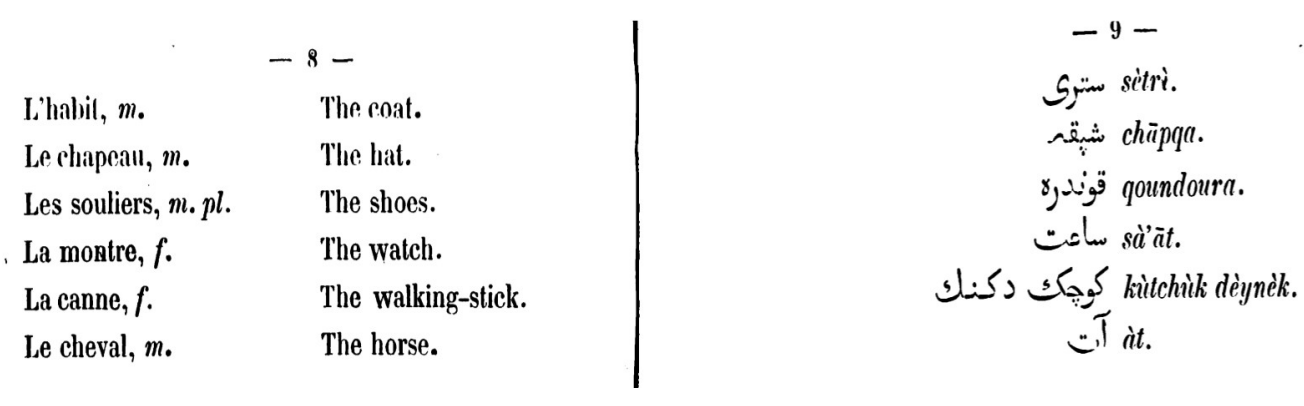

Söz varlığı için sıklığı yüksek ve en gerekli 170 kelime verilmiştir. Eserin 2. kısmında kolay ibareler başlığı altında örnek olarak verilen cümleler, en çok kullanılan cümleler; zor ibareler başlığı altında örnek olarak verilen cümleler ise daha uzun ve birleşik yapılı cümlelerdir. Diyaloglarda cümleler kısadır. 


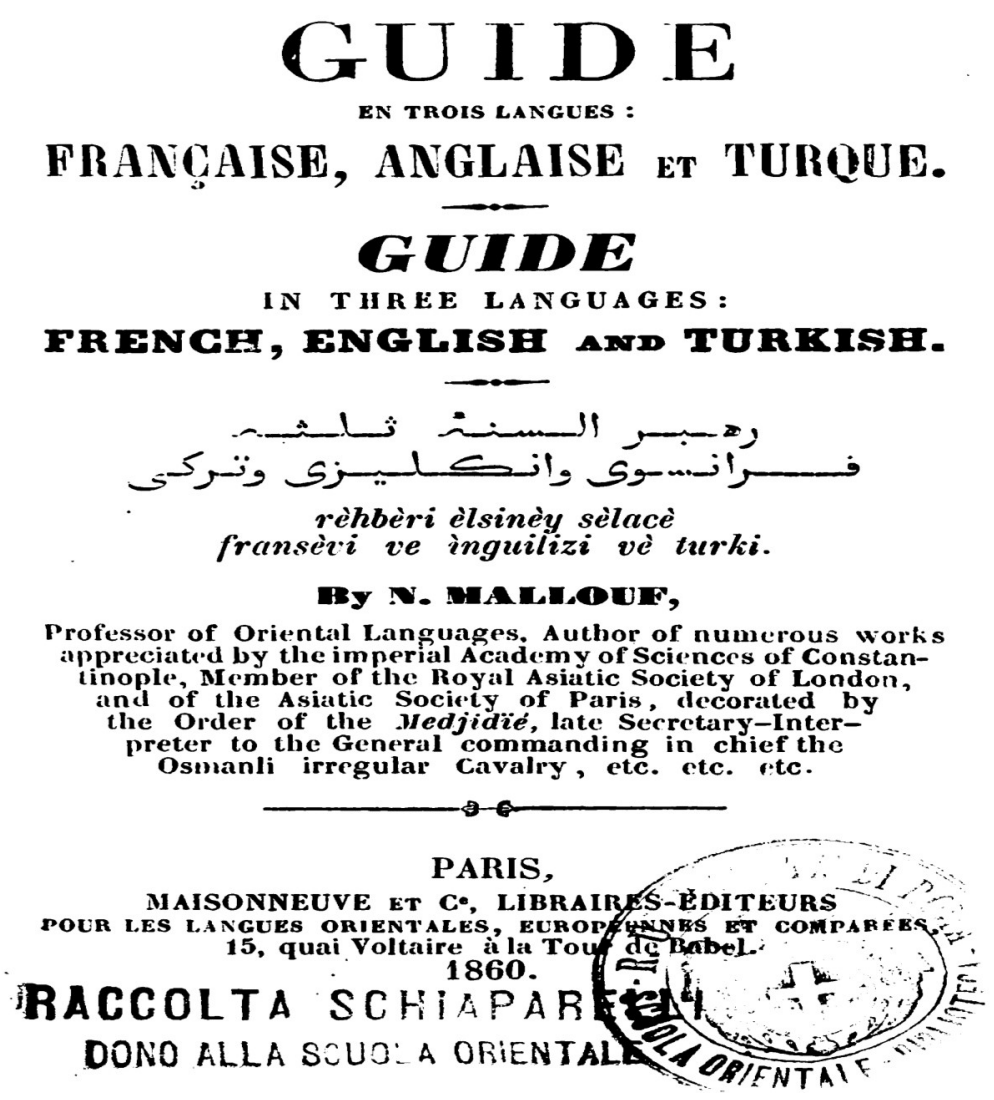

\section{Türkçe-Fransızca-Almanca}

Catergian, P. S. (1855). De Conversation Turc-Français-Allemand. Vienne: İmprimerie des Méchitharistes: Alfabe listesiyle başlayan eserde sayfa solunda Osmanlı Türkçesi, sağında transkripsiyonlu hali, devamındaki sayfanın solunda Fransızcası, sağında Almancası bulunur. Çeşitli konularda konuşmalar yer alır. 204. sayfadan itibaren sayılar, aylar ve günler verilmiştir.

\section{Sonuç}

İnsanlar çok dil edinmeyi eskiden beri istemiştir. Bunun sonucu olarak ortaya çok dil öğreten eserler çıkmıştır. Transkripsiyon metinleri kapsamında değerlendirilen çok dilli eserler sadece dil öğretmez, dil öğretmenin yanında şu faydalar da görülür:

1. Bir dilin çok dilli bir eserle kayda geçtiği tarihteki ses, biçim, anlam özelliklerinin karşı dillerdeki durumuna bakılarak anlaşılabilmesini sağlar. Rosetta taşının çözümü çok dilli olması vesilesiyledir.

2. Çok dilli dil öğretim materyallerinden sayılan bu eserler, günümüz dil öğretim veya çeviri çalışmalarında bir prototip hüviyetindedir. Bu eserler zamanın çeviri makineleridir.

3. Bu eserlerle kelime alışverişinin tarihini de tespit etmek mümkün olmaktadır. Hangi dil, hangi başka dilden hangi kelimeleri almışsa bu eserlerde kolayca belirlenebilmektedir. 
4. Bu eserler, günümüzde bu dillerin mensuplarını bir araya getirip ortak çalışma yapmalarına vesile olabilmekte, ortak eserler hazırlanmasına zemin hazırlamaktadır.

5. Bu eserlerin büyük kısmının Kırım Savaşı öncesi ve esnasında yazıldığı dikkate alındığında askerî ilişkiler için önemi ortaya çıkmaktadır.

6. Böyle eserlerin filoloji bölümlerince çalışlıp bilim dünyasına sunulması da ayrıca önemli bir konudur.

\section{Kaynakça}

Aksan, D. (1995). Her Yönüyle Dil Ana Çizgileriyle Dilbilim (8 b.). Ankara: TDK.

Aksan, D. (1995). Her Yönüyle Dil ve Ana Çizgileriyle Dilbilim. Ankara: TDK.

Atuf, M. (1868). Dictionnaire Français-Turc-Italien. Constantinople: Imprimerie du Djeridei-Havadis.

Bekar, B. (2016). 1788 Yılında J. M. Korabinsky Tarafından Yazılmış Türkçe Gramer Kitabı. RumeliDE Dil ve Edebiyat Araştırmalar Dergisi(7), 20-34.

Besse, J. C. (1829). Abrégé de la grammaire turque : contenant, outre les principes de cette langue, des idiotismes, des discours familiers, et un petit vocabulaire en franc, ais, turc et hongrois. Pest: $\mathrm{O}$. Wigand.

Catergian, P. S. (1855). De Conversation Turc-Fran.ais-Allemand. Vienne: İmprimerie des Méchitharistes.

De Besse, J.-C. (1838). Voyage en Crimée, au Caucase, en Géorgie, en Arménie, en Asie-Mineure et à Constantinople en 1829 et 1830. , . Paris: Delaunay.

Handjeri, A. (1841). Français-Arabe-Persan et Turc. Moscou: De L'Imprimerie de L’Université Impériale.

Holdermann, J. B. (1730). Grammaire Turque Ou Methode Courte Et Facile Pour Apprendre La Langue Turque. İstanbul: Dâr-ı Trbâa-yı Âmire.

Holdermann, J. B. (1776). Turetskaya Grammatika. Petersburg.

Holdermann, J. B. (1777). Turetskaya Grammatika. (R. Gablitsl, Çev.) Moskva: Pri İmperatorskom Universitet.

Kononov, A. N. (2009). Rusya'da Türk Dillerinin Araştırılması Tarihi. (K. V. Nerimanoğlu, N. Muradov, \& Y. Sevimli, Çev.) Ankara: TDK.

Letellier, V. (1838). Vocabulaire Oriental, Français-Italien, Arabe, Turc et Grec Pour la Seule Prononociation. Paris: Guyot et Scribe, Barrois, et Dondey-Dupre.

Letellier, V. (1848). L'Impitoyable, journal de tous les abus publics. Paris.

Littéraire, L. F. (1833). La France Littéraire ou Dictionnaire Bibliographique (Cilt 5). Paris: Firmin Didot Freres.

Mallouf, N. (1860). Guide en trois langues: Française, Anglaise et Turque. Paris: Maisonneuve.

Malouf Samaha, C. (2010). Nassif Mallouf Dragoman and Orientalist (1823-1865). İstanbul: İsis.

Meninski, F. a. (1680). Grammatica Turcica. Vienne.

Parastatov, S., \& Kondrasheva, A. (2018). Academic studies of the black sea region and the northwest caucasus (second half of the 18 th to the early 19th century),. D. Gutmeyr, \& K. Kaser içinde, Europe and the Black Sea Region A History of Early Knowledge Exchange (1750-1850); (s. 313335). Zurich: Verlag.

Topaloğlu, A. (1989). Dil Bilgisi Terimleri Sözlüğü. İstanbul : Ötüken .

Yllmaz, Y., \& Aksoy, C. (2019). Besse'nin Grammaire Turque’ü ve eserindeki idyotizmler. RumeliDE Dil ve Edebiyat Araştırmaları Dergisi(Ö5), 83-93. 
Yılmaz, Y., \& Doğan, C. (2019). Nassif Mallouf ve üç dilli rehber kitabı: Rehber-i elsine-yi selâse: Fransevî ve İngilizî ve Türkî. RumeliDE Dil ve Edebiyat Araştırmaları Dergisi, 94-103.

Yılmaz, Y., \& Özkaya, H. (2017). Beş dilli gramer kitabı: Vocabulaire Orientale Français-Italien, Arabe, Turc et Grec. VII. Uluslararası (s. 575-581). Çanakkale: ULEAD.

Yılmaz, Y., \& Toktar, S. (2017). Transkripsiyon anıtlarına göre yabancıların Türkçe öğrenme gerekçeleri. VII. Uluslararası Eğitimde Araştırmalar Kongresi (s. 1). Çanakkale: ULEAD.

Yılmaz, Y., \& Toktar, S. (2019). Holdermann'ın Grammaire Turque'ünün 1777 Tarihli Rusça Çevirisi: Turetskaya Grammatika. I. Uluslararast Sosyal Bilimler Sempozyumu 13-14-15 Ekim 2016 Asos Congress Bildiri Kitabı (s. 3179-3192). içinde Elazığ: Asos. 